\title{
Khedivial Cairo: An Evolved Metabolism
}

\author{
Eman Mamdouh Abdel Sabour ${ }^{1}$ and Stephen Luoni ${ }^{2}$ \\ 1. Department of Architecture and Urban Design Program, German University, Giza 12111, Egypt \\ 2. Department of Community Design, University of Arkansas Community Design Center, Arkansas 72701, United States
}

\begin{abstract}
Metabolism such as Cairo evolves rabidly, to transform existing urban spaces. The result of transformation process may lead to the loss of the original space qualities. Opera and Ataba squares are junction space which is one of these urban spaces that meanwhile is suffering from this process. This junction space is between two unique urban structures Fatima Cairo and Down town Cairo. This urban structure needs to be a grand civic expression of the 19th century urban system with the new energies of the functionalist city. This Gordian knot of elevated highways, congested surface roads, extensive automobile parking and sprawling informal markets will be integrated into a new open space system that optimizes the city's intensified energies. This paper discusses urban structure transformation of the junction space urban structure timeline. Ending with a proposal finally transforms this space into a sustainable urban development.
\end{abstract}

Key words: Urban spaces, Khedivial Cairo, sustainable urban development, district transformation.

\section{Introduction}

Now located within a city of 17 million persons, the urban structure of 19th century Khedivial Cairo was planned when the city's population consisted of only 350,000 people. The metabolism of Cairo has since evolved, along with its structures of social and economic exchange, transportation, urban ecology and its imagination—or comprehensibility. The 19th century structure of urban spaces requires adaptive reuse to address overdevelopment brought on by contemporary densities and movement systems in this emergent global megacity.

The aim of this study is to discuss people's adaptive reuse design proposal for Opera and Ataba Squares, the heart of Khedivial Cairo (Fig. 1). The paper will examine the transformations in the urban structure of Opera-Ataba Squares and the adjoining district between 1870 and 2010, as they relate to the sustainable urban development plan for 2030. The proposal suggests an ecological urbanism that reconciles the grand civic expressions of the 19th

Corresponding author: Eman Mamdouh Abdel Sabour, M.Sc., research field: sustainable urban design. E-mail: eman_sabour@yahoo.com. century urban system with the new energies of the functionalist city. This Gordian knot of elevated highways, congested surface roads, extensive automobile parking and sprawling informal markets will be integrated into a new open space system that optimizes the city's intensified energies.

The DNA (deoxyribonucleic acid) of 19th century urbanism is recombined with a 21st century vertical urban order that manages an unprecedented magnitude of resource flows in four novel spaces: (1) an extended Opera Mall; (2) an Ataba Square Covered Market Plaza and Flyover Gateway; (3) the Hamdi Seif Al Nasr Multiway Boulevard; and (4) the new Great Lawn of Azbakiyya Garden. These four spaces deliver new ecological services combined with the expansion of urban services towards a new sustainable Cairo.

\section{Opera-Ataba District Background}

In preparation for celebrations surrounding the grand opening of the Suez Canal [1], Khedivial Cairo's urban structure was planned using current European fashions of the time. Inspired by Haussmann's work in Paris, the urban plan included an Opera House lining the main square [2]. Ever since, 


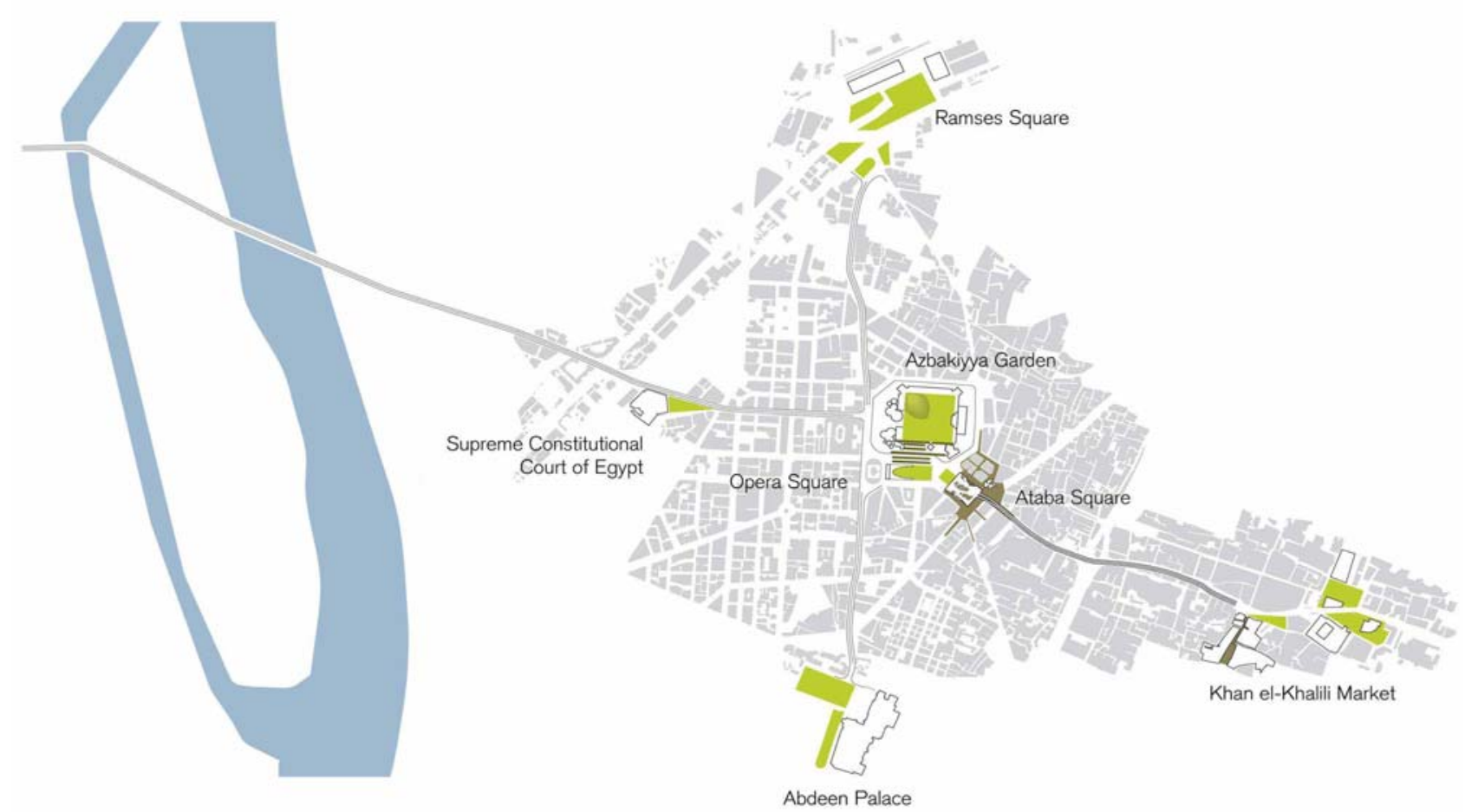

Fig. 1 Opera-Ataba district is the heart of Khedivial Cairo. Source: author own work with University of Arkansas community design center.

the square has been known as Opera Square. The construction of the Opera House was accompanied by numerous other edifices that incorporated 19th century revivalist and eclectic features characteristic of the period. Most of these structures are now listed as heritage buildings due to their significant architectural and aesthetic value [3]. The adjoining Ataba square predates Opera Square, and its edges were also reconfigured to accommodate the new French order. Ataba Square still has many treasured heritage buildings along its boundaries including a fruit and vegetable market, hotels, department stores, a fire station and the prominent Ataba main post office. As expected in this particular urban order, Opera and Ataba Squares marked the crossroads of main thoroughfares and collectively came to be seen as the heart of Cairo. A large expanse of land between Opera and Ataba squares was designated for Azbakiyya Garden [4], one of Cairo’s rare public recreational and cultural parks. Egypt's largest a second-hand and antiquarian book market sprang up and flourished alongside the garden perimeter fence, as the city pushes into the edges of this green refuge.

What was once the pride and joy of Khedive Ismail's vision of a glorious "Paris of the East" [5] has suffered great deterioration due to general neglect and failure to restore the opera house after a devastating fire in 1971. The combination of Opera and Ataba squares originally formed a major cultural and recreational node, which has evolved into one of Cairo's main transportation hubs. In addition to the street network (Fig. 2) that now sees sponsors heavy motor traffic, other means of transport figure prominently. A major subway node with three metro lines (first line: Helwan-Marg, second line: Giza-Shobra, and third line: Imbaba-Cairo Airport) which is underneath Opera-Ataba Squares connect the heart of Khedivial Cairo with the rest of greater Cairo. An adjacent bus terminal houses thirty bus routes that radiate out to serve greater Cairo. The two squares are currently separated by the Opera Square multi-story car park built on the site of the burned out Khedivial Opera House. 


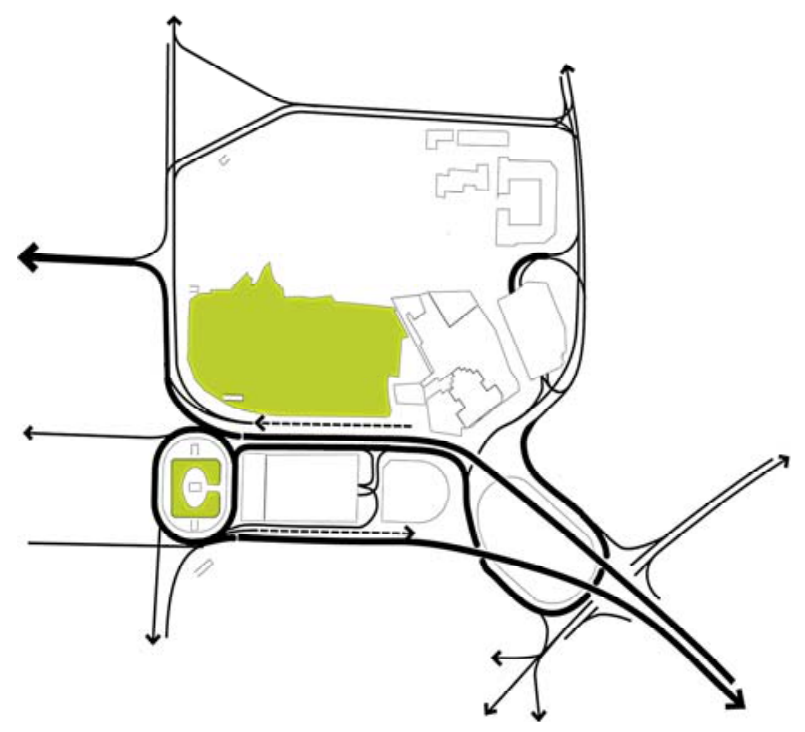

Current Traffic Solution

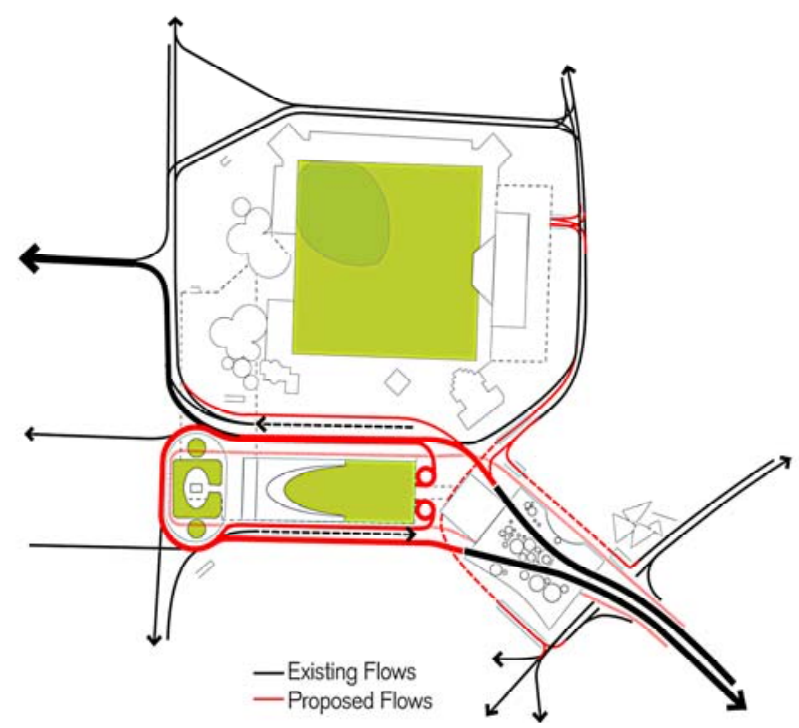

Proposed Traffic Solution

Fig. 2 Street pattern diagram comparing between current traffic solutions and proposed traffic solutions. Source: Author own work with University of Arkansas community design center.

\section{District Urban Transformation}

\subsection{Birth of Khedivial Cairo-1870}

As historian Scharabi [3] states: “Cairo's multifaceted, multiform appearance today is the result of an extraordinary collision between the Orient and the Occident”. Khedivial Cairo's metabolism materialized from a European urban structure based on a gridiron plan overlain with oblique boulevards, anchoring squares and traffic roundabouts. In contrast to the medieval fabric of Islamic Cairo to the west, the district street plan for this undeveloped land near the Nile was clearly defined through geometric principles, and a tidy bourgeois order of mixed-uses alien to the more porous Arab sector landmarks, such as the Opera House and Azbakiyya Garden (Fig. 3), establish a western type of urban representational order. This newly born structure offered a European lifestyle featuring enjoyable outdoor public spaces uncommon to Cairo.

\subsection{Deterioration of Khedivial Cairo-1952}

After the 1952 revolution, the district started to lose its fine polished urban qualities as a result of policies that forced land reforms and intensive and unsympathetic construction. Historic buildings were subject to rent freezes, leaving little capital for maintenance and repair. This led to the rapid deterioration of several buildings [6]. The ensuing exodus of a large part of the foreign community after the revolution contributed to further degradation in quality of the urban space due to changing uses exercised by a burgeoning local community. An informal economy overtook these civic spaces developing for a cultural and foreign elite. Even the use of the Opera House changed from international orchestral performances and ballet to local Arabic music concerts. The degradation of the street system started in 1960, when on July 26th, street cut through the heart of Azbakiyya Garden leading to serious deterioration. This was greatly exacerbated in 1971 when a great fire engulfed and destroyed the Opera House, and destroyed many of the other architectural treasures distinguishing the district. The cultural heart of Khedivial Cairo was then transformed into a down-at-heel residential district with chronic traffic congestion that has overwhelmed the district. 

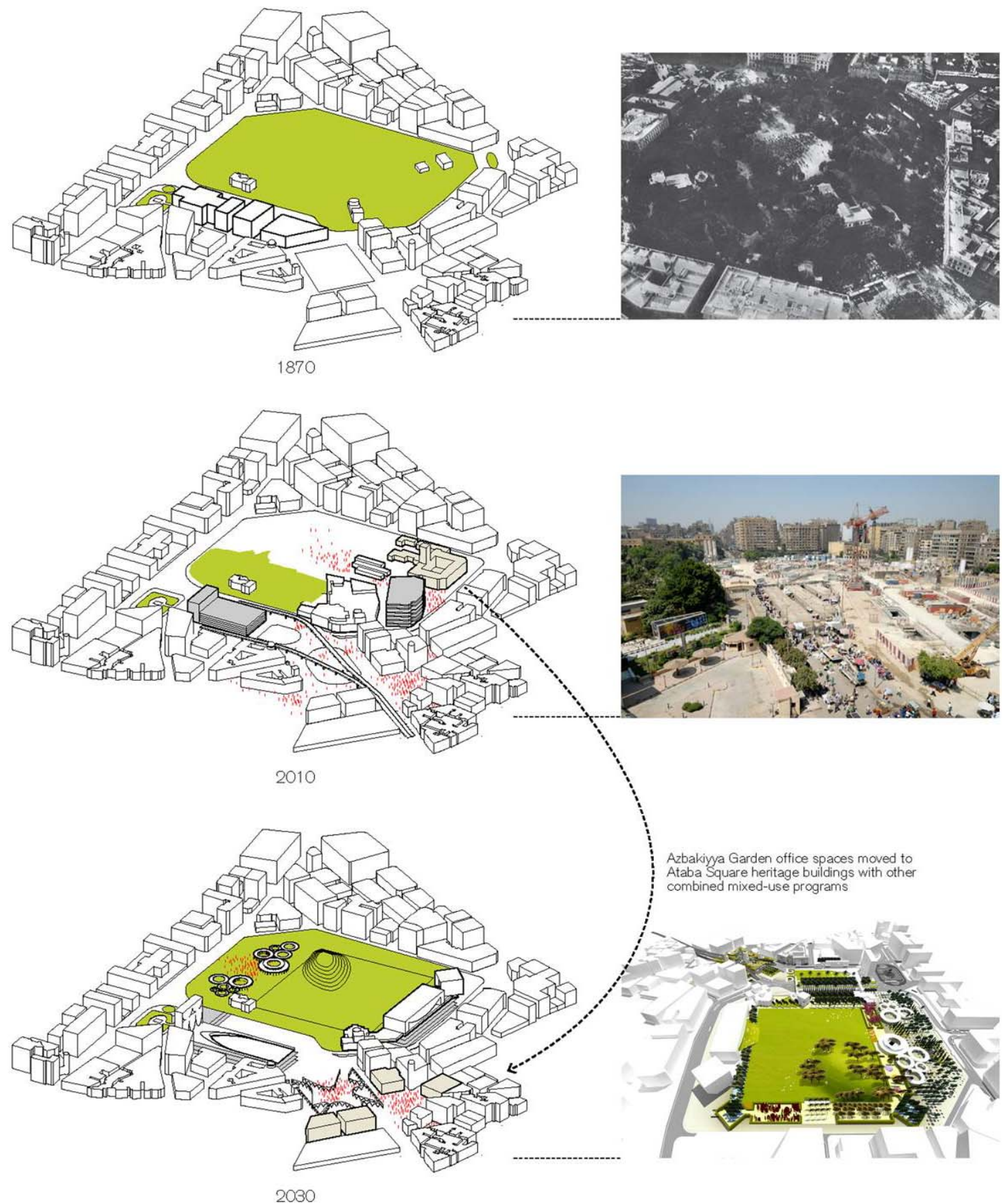

Fig. 3 Azbakiyya Garden as a major indicator for the district transformation process between 1870 and 2030 . Source: Author own work with University of Arkansas community design center.

\subsection{Endangered Khedivial Cairo-2010}

The 19th century Cairo metabolism for which the Khedivial infrastructure was designed grew more imbalanced over the last 40 years as densities and demographics changed. Residential use declined throughout the district, as it became increasingly given over to heavily commercial and administrative functions. The need for a traffic strategy is all too apparent. Attempts to resolve the traffic crisis started with the construction of Al-Azhar "flyover" Bridge, followed by the creation of Al-Azhar Tunnel, only to 
exacerbate the traffic problem. Traffic overloads have spilled into public spaces, as the separations between traffic and pedestrian realms have turned anarchic. Circulation dysfunctions are not limited to the endless traffic jams and heavy pollution, but fenced-off pedestrian walkways have also undermined connectivity within the district. Arterial throughways like the Al-Azhar Bridge have supplanted the role of public space in organizing the city, creating a clear need to restructure the district's identity through implementation of a coherent plan that restores definable roles for public spaces. The Opera-Ataba district serves as a pivotal location for all socio-economic classes among the population, both in daily life and in needs and special events. However, its appreciable role is threatened by the increasing social polarization between informal sectors and wealthy communities. The area is currently in a very sorry state. If degeneration continues at this rate more urban value will be lost as the rate of deterioration could soon wipe out district's charm and cultural and heritage.

\subsection{Sustainable Khedivial Cairo-2030}

Sustainable urban development by definition integrates with environmental, economic and social issues-a triple bottom line-underpinning the sustainable development of cities as Curwell et al. [7]. Although Khedivial Cairo suffers dramatically in both environmental and social aspects, the economic capital of the district can be a starting point for the redevelopment process. This proposal adapts a redevelopment strategy based on improvements to Azbakiyya Garden that enhances the delivery of urban and ecological services while providing new sources of revenue through new performance venues. Redevelopment of highways into multiway Green Boulevards and the provision of new market spaces underneath flyover bridges complement the re-establishment of Azbakiyya Gardens. The proposal aims to recapture a more pedestrian-friendly, connected public realm responsive to the explosive population growth and its informal market economies.

The proposal (Fig. 4), seeks transit-supportive land-use development patterns and that promote "walkability" and access without need for an automobile. Public transit and walkable neighborhoods work hand-in-hand since everyone is a pedestrian at the beginning and ending of a transit trip. Sustainable Khedivial Cairo is pedestrian friendly, pedestrians can circulate at the core of the area to markets and Azbakiyya Garden without the need to cross congested and dangerous streets (Fig. 5). This self-sufficiency is rewarded with increased safety, improved access, higher energy efficiencies (decreasing the amount of fossil fuels used), increased public health (by facilitating physical activity), and better environmental stewardship from reductions in automobile $\mathrm{CO}_{2}$ emissions.

The area proposed sustainable development plan interventions are divided into four major spaces: opera greensward (Fig. 6), gateway (Fig. 7), Hamdi Seif Al Nasr Multiway Boulevard (Fig. 8) and Great Lawn of Azbakiyya Garden (Fig. 9).

\section{Four Innovative Spaces}

\subsection{Opera Greensward}

Opera Square is extended into a new public greensward with new outdoor performance space, a gateway landmark and an intermodal transportation hub with underground parking (Fig. 10). The proposed gateway structure, harboring a dot screen pattern of the former Opera Hall House, reclaims the lost civic quality of the square's eastern edge. Housing a visitor overlook at the top, the gateway provides a new backdrop and staging for performance venues on the expansive greensward atop the metro and automobile parking underneath. Opera Greensward re-establishes a civic anchor recalibrated to the new social energies of a larger Cairo. Meanwhile in Ataba Square, a new large "Covered Market Plaza" and "Flyover" will facilitate rich commercial and cultural experiences. 


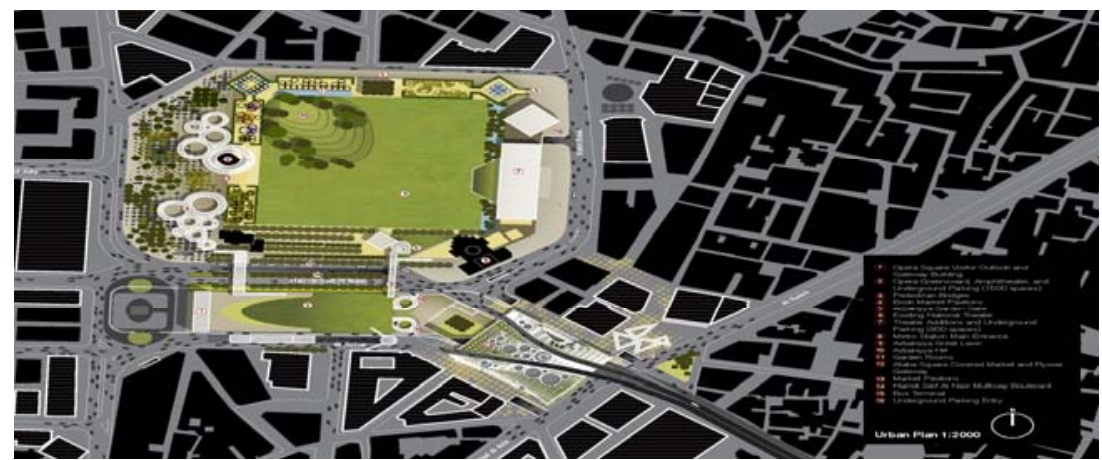

Fig. 4 Opera-Ataba district sustainable development proposal, main layout showing proposal major four innovative spaces. Source: Author own work with University of Arkansas community design center.

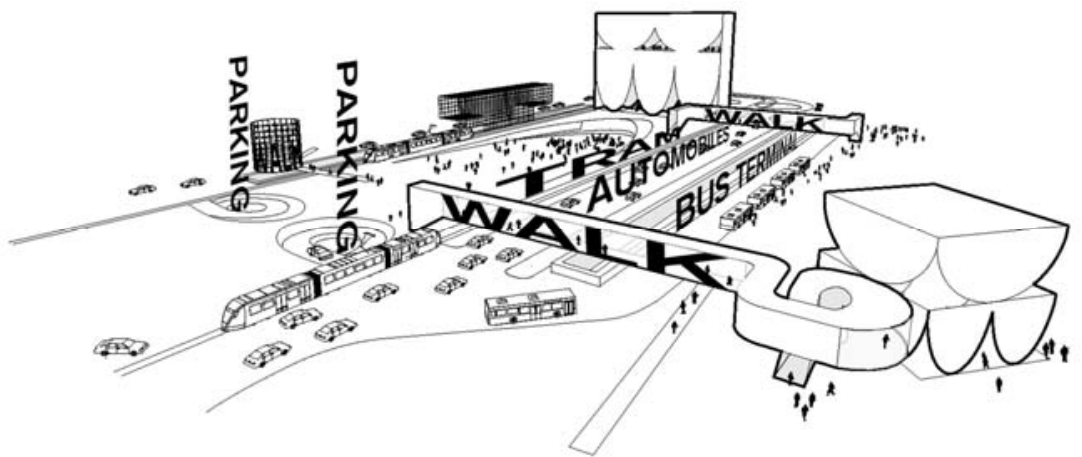

Fig. 5 Diagram showing the walkability proposed development. Source: author own work with University of Arkansas community design center.

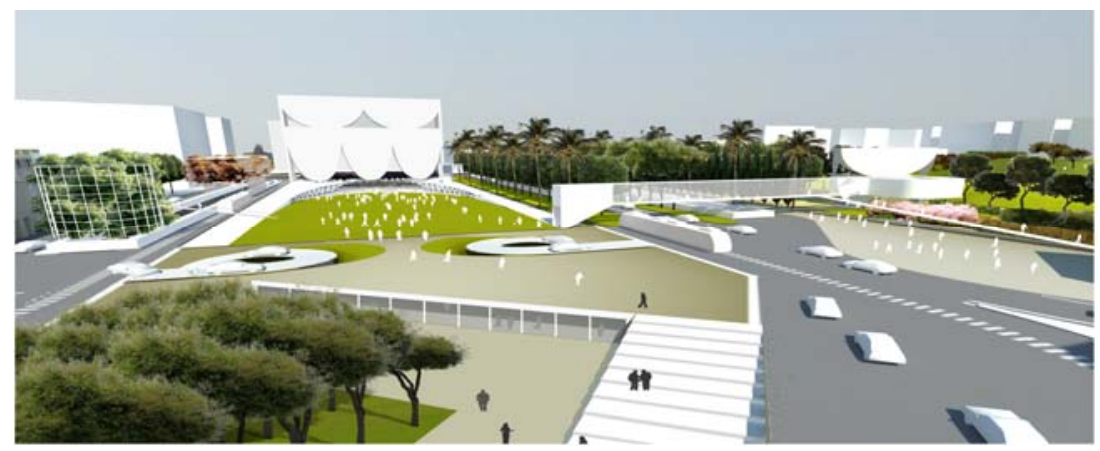

Fig. 6 Illustration for: Opera Green sward and Hamdi Seif Àl Nasr Multiway Boulevard, open space is extended into a public greensward with new outdoor performance space, a gateway landmark, and an intermodal transportation hub with underground parking. Source: Author own work with University of Arkansas community design center.

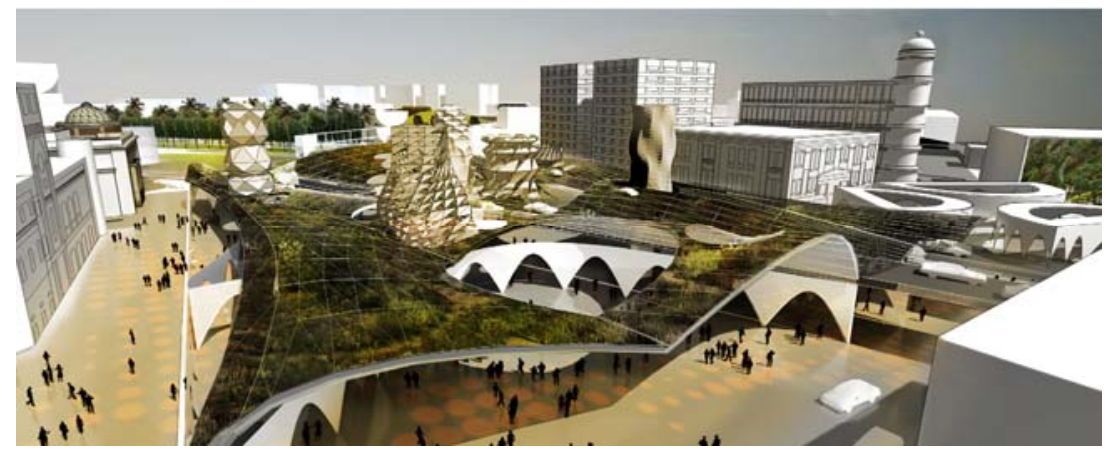

Fig. 7 Ataba square covered market xeriscape roof garden and flyover gateway. Source: Author own work with University of Arkansas community design center. 


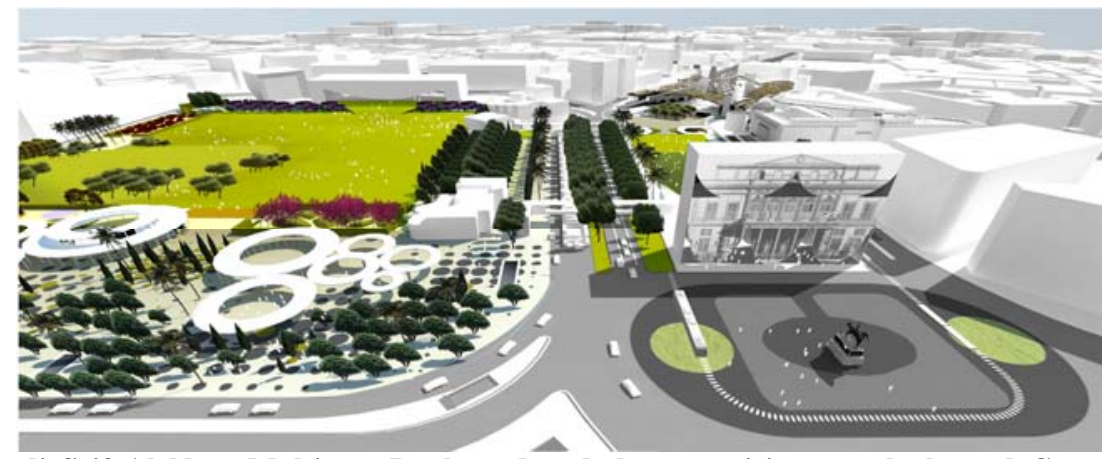

Fig. 8 View of Hamdi Seif Al Nasr Multiway Boulevard and the new visitor overlook, and Gateway building. Source: Author own work with University of Arkansas community design center.

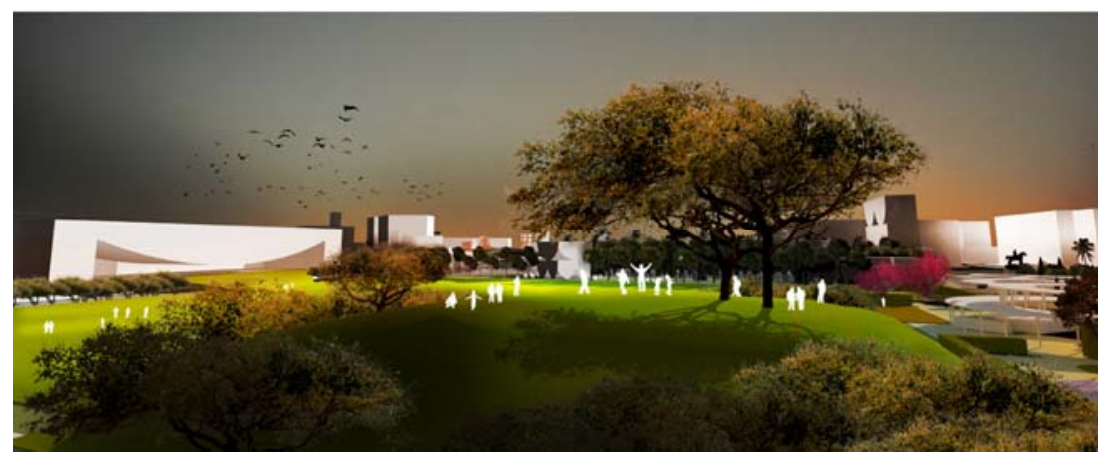

Fig. 9 Illustration for Azbakiyya Garden proposed development. Source: Author own work with University of Arkansas community design center.

\subsection{Gateway}

Recognizing the necessity for flyover expressways to relieve surface traffic, a new "mat building” (Fig. 11) reorganizes the surface of Ataba Square as a covered pedestrian zone to accommodate spillover market activity. The Flyover Gateway atop the mat structure (Fig. 12) civilizes rogue highway engineering structures through a mat urban prototype that can be sequentially implemented throughout Cairo. This vertical urbanism shapes and shelters a climate-friendly pedestrian landscape underneath while proposing an automobile-scaled landscape above with green roofs and ventilation towers that function as urban lanterns. The mat prototype is an exemplary urban solution since it multiplies the urban surface (and shade), laminating functions of conflicting scales and speeds in the same space. The pedestrianization and enhanced liveability (Fig. 13) of Ataba Square are accompanied by land-use changes that favor a more contextual mix of residential, office and live-work functions.

\subsection{Hamdi Seif Al Nasr Multiway Boulevard}

A new multi-way boulevard integrates dedicated flow paths for various transportation modes involving bus, rail, auto and pedestrian lanes. A cross grain of pedestrian bridges and tunnels establish new connections between Opera Greensward and Azbakiyya Garden. The vegetated multiway boulevard mitigates heat island effects while facilitating improved intermodal transportation services due to the relocation of the bus station and new tram service on the boulevard. This well-regarded street type introduces a resourceful and efficient traffic planning tool complementary to the urban planning vocabulary that defines Khedivial Cairo.

\subsection{Great Lawn of Azbakiyya Garden}

A new great lawn, terminating at "26th of July" Axis, provides an urban refuge while organizing 


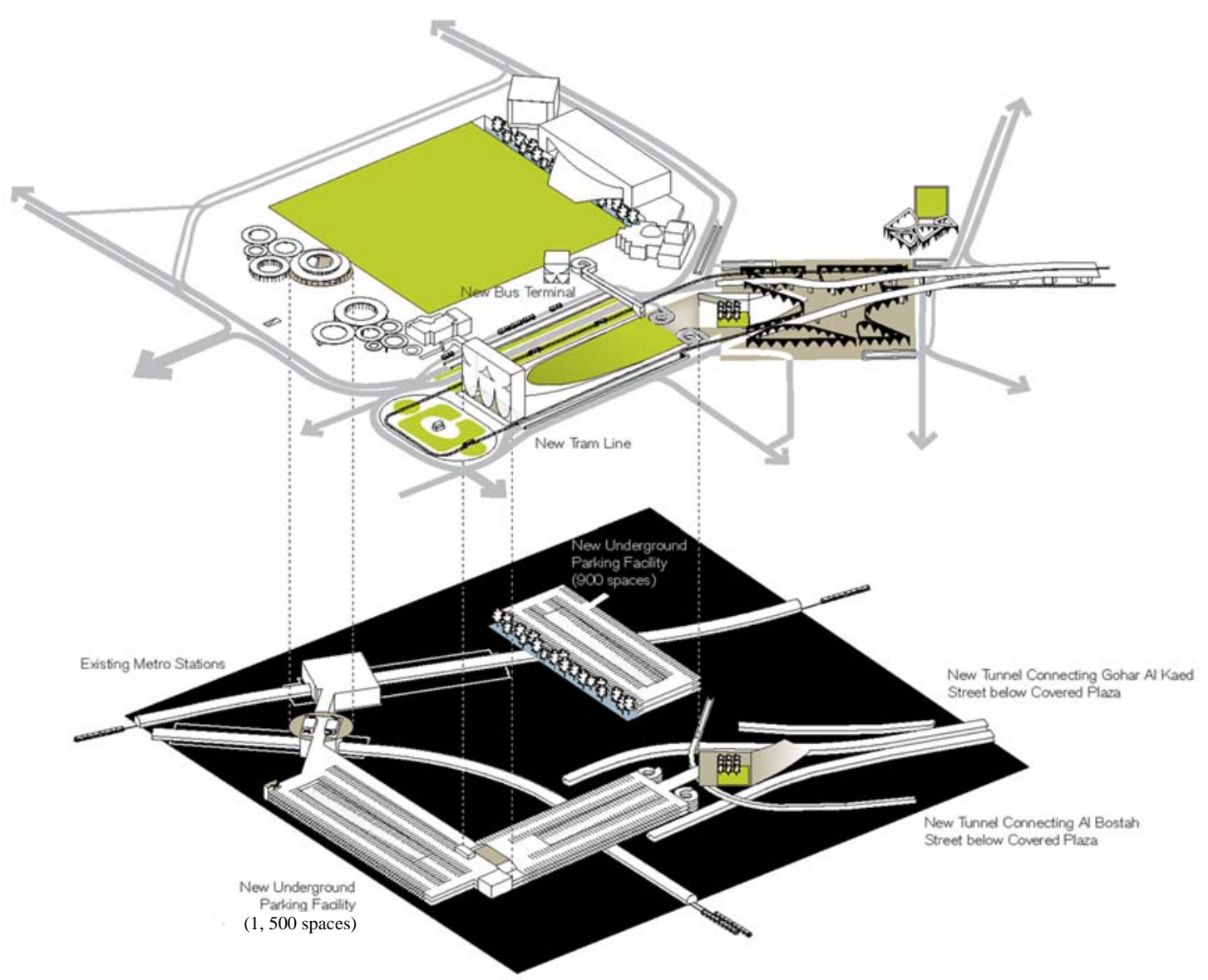

Fig. 10 intermodal transportation hub with underground parking. Source: Author own work with University of Arkansas community design center.

peripheral cultural programs on a more intimate scale. The northwest quadrant of the four-square lawn is punctuated by a large artificial hill that overlooks Opera and Ataba Squares, while making this green landscape visible to those outside of the gardens. The garden periphery is composed of fusion landscapes that celebrate both Arab and Western place-making traditions. Indeed, proposed water features, typical in the most celebrated Arab gardens, will function in tandem with a convective cooling infrastructure located beneath Azbakiyya Garden. The periphery gardens re-establish a well-defined and orderly transition between bustling streets and quiet gardens inside. The Azbakiyya book market is also relocated adding both physical and cultural values to the garden's new configuration. The garden periphery absorbs the casual siting of the metro facilities and relocation of the book market to a shaded plaza at the western edge. Opposite this, a catenary theater structure terminating the "26th of July" Axis extends the National Theater complex to create both garden and street frontages.

The greensward, lawn, multiway boulevard, covered market and flyover gateway reconstitute a symbolic urban structure for this section of Cairo that is more aligned to the metabolism of a new 21st century Cairo. The resiliency and metropolitanism within the imported 19th century order readily support fusion of Arab and Western traditions. Reconfiguring the urban surface into new sectional or vertical formats, these urban landscapes evolve hybrid conditions that deliver new urban and ecological services. New ecological services include urban climate conditioning, carbon sequestration, humidification, amplification of habitat 


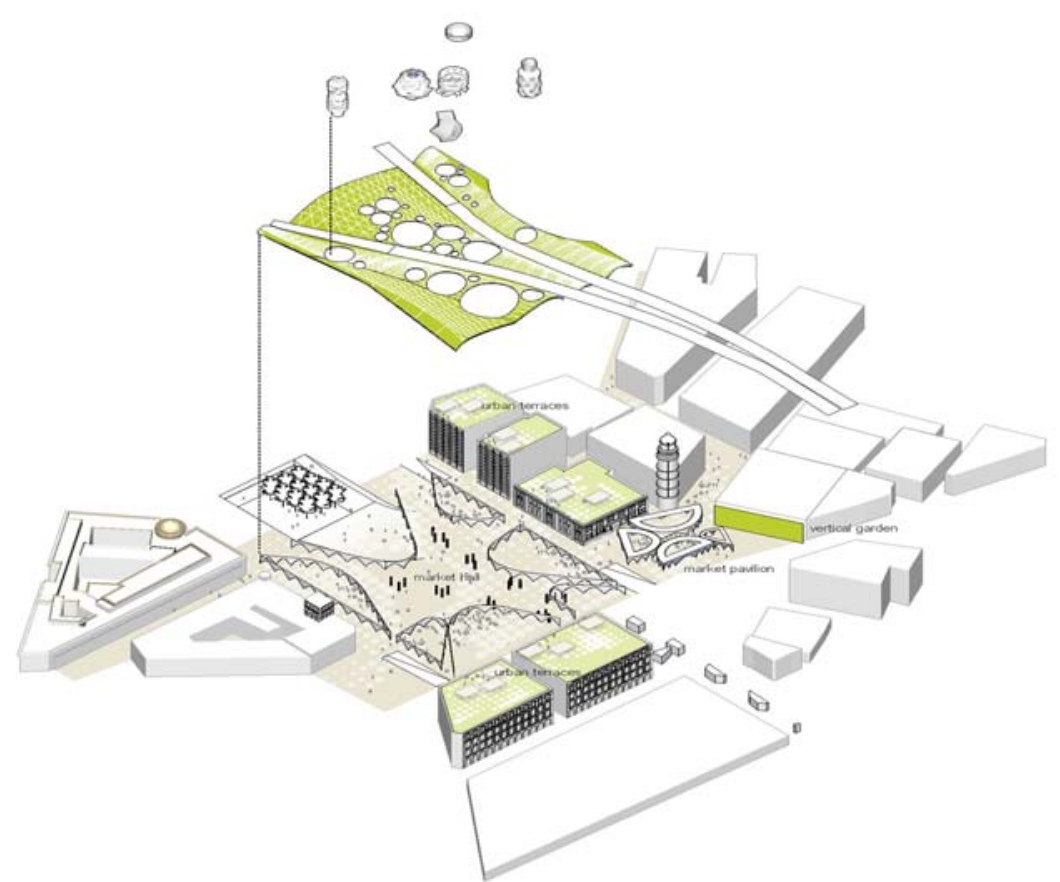

Fig. 11 Diagram showing the “mat building”. Source: Author own work with University of Arkansas community design center.

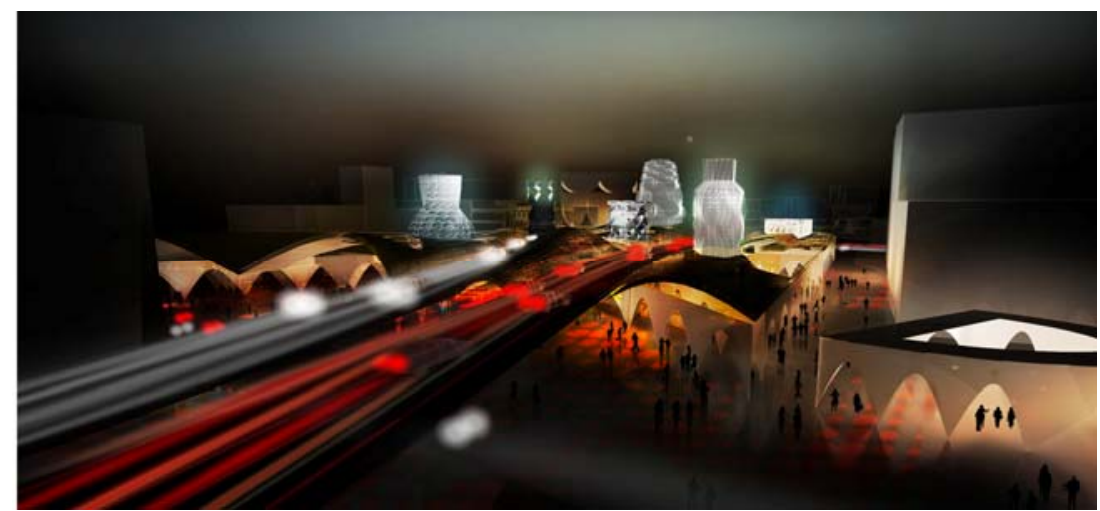

Fig. 12 Ataba square covered market and flyover gate, recognizing the necessity of flyover expressways to relieve surface traffic, a new "mat building” reorganizes the surface Ataba square as covered pedestrian zone to accommodate spillover market activity. Source: Author own work with University of Arkansas community design center.

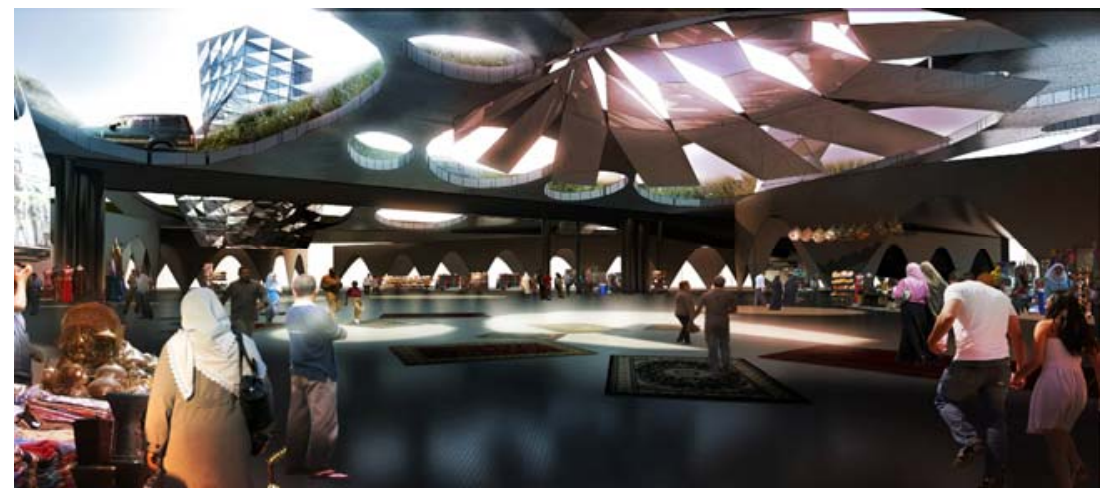

Fig. 13 View under Ataba square covered market hall. Source: Author own work with University of Arkansas community design center. 
and biodiversity, mitigation of heat island effects, improved aesthetics and recreation. Enhanced urban services include increased connectivity and way finding, coordination of intermodal transportation, greatly enhanced pedestrian and market realms, and innovative street types that address traffic problems unique to the bourgeoning megacity. When managed well, this unprecedented intensity can be the material from which a magical urbanism can accommodate ever more social conquest of the city.

\section{Conclusions}

The aim of this study is to eliminate continues degradation by proposing a design for Opera and Ataba Squares, in the heart of Khedivial Cairo. Reconfiguring the urban surface into new sectional or vertical formats, these urban landscapes evolve hybrid conditions that deliver new urban and ecological services. New ecological services include urban climate conditioning, carbon sequestration, humidification, amplification of habitat and biodiversity, mitigation of heat island effects, improved aesthetics and recreation. Enhanced urban services include increased connectivity and way finding, coordination of intermodal transportation, greatly enhanced pedestrian and market realms, and innovative street types that address traffic problems unique to the bourgeoning megacity. When managed well, this unprecedented intensity can be the material from which a magical urbanism can accommodate ever more social conquest of the city.

\section{References}

[1] J.A. Lughod, Cairo: 1001 Years of the City Victorious, Princeton University Press, Princeton, New Jersey, USA, 1971.

[2] T. Mitchell, Colonizing Egypt, University of California Press, Berkeley, Los Angeles, London, 1991.

[3] M. Scharabi, Cairo: City and Architecture in the Era of European Colonialism, Verlag Ernst Wasmuth, Tübingen, 1989. (in German)

[4] A. Raymond, Cairo: City of History, the American University in Cairo Press, Cairo, Egypt, 2001.

[5] C. Myntti, Paris along the Nile: Architecture in Cairo from the Belle Époque, The American University in Cairo Press, Cairo, 1999.

[6] J. Amedi, H. Nagler, C. Wessling, The Importance of Urban Renewal in the Historic District for the Development of Great Cairo, Jahrbuch Stadterneuerung, Schwerpunk, Berlin, 2009.

[7] S. Curwell, M. Deakin, M. Symes, Sustainable Urban Development Volume 1, The Framework and Protocols for Environmental Assessment, Routledge, London and New York, 2005. 